\title{
Evaluation of semen collected by electroejaculation from captive lesser Malay chevrotain (tragulus javanicus).
}

\begin{abstract}
Thirteen sexually mature captive male lesser Malay chevrotains (Tragulus javanicus) were each anesthetized twice with tiletamine-zolazepam for electroejaculation. Viable spermatozoa were collected from all animals. The semen was creamy, milky, pale yellowish, or watery. The mean values for ejaculate volume, sperm concentration, and percentages of sperm motility, normality and viability were $23.7 \pm 2.5 \mu 1,366.9 \pm 127.8 \times 10$ spermatozoa $/ \mathrm{ml}$, $40.0 \% \pm 3.1 \%, 71.4 \% \pm 1.6 \%$, and $59.6 \% \pm 2.1 \%$, respectively. Semen pH was $7-8$. No adverse effects of electroejaculation were noted. These are the first reported values for semen of lesser Malay chevrotain. Electroejaculation should be usable for routine semen collection in this species.
\end{abstract}

Keyword: Electroejaculation; Lesser Malay chevrotain; Semen collection; Semen evaluation; Tragulus javanicus. 